九州大学学術情報リポジトリ

Kyushu University Institutional Repository

Nanxiu Qian, Richard J. Smith, and Bowei Zhang, eds. Rethinking the Sinosphere: Poetics, Aesthetics, and Identity Formation. Amherst, NY: Cambria Press, 2020.

SIXIANG WANG

University of California, Los Angeles: Assistant Professor

https://doi.org/10.5109/4377709

出版情報: Journal of Asian Humanities at Kyushu University. 6, pp.91-92, 2021-03. Kyushu University, School of Letters, Graduate School of Humanities, Faculty of Humanities バージョン:

権利関係 : 


\title{
Nanxiu Qian, Richard J. Smith, and Bowei Zhang, eds. Rethinking the Sinosphere: Poetics, Aesthetics, and Identity Formation. Amherst, NY: Cambria Press, 2020.
}

\author{
BOOK REVIEW BY SIXIANG WANG
}

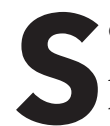

CHOLARS of premodern and early modern East Asia have in recent years renewed their attention to cultural practices that endow the region with its analytical and historical coherence. A cosmopolitan intellectual effort, Rethinking the Sinopshere: Poetics, Aesthetics, and Identity Formation addresses these shared practices from the tenth to the nineteenth century, with contributions from leading scholars in the United States, China, Korea, Singapore, and the Netherlands. This is the second volume in a two-volume series edited by Nanxiu Qian, Richard J. Smith, and Bowei Zhang. Whereas the first volume covers questions of circulation, the intersections of gender, class, and religion, and the evolution of these practices in the twentieth century, this second volume is devoted to literary interactions, historical motifs (both also covered in part 1 of this volume), and the evolution of aesthetic and poetic forms (the focus of part 2).

The "Sinosphere," as conceived throughout this book, denotes the "cultural sphere of Chinese written characters" sustained by circulations of people, books, ideas, and, most importantly, texts. Rejecting the center-periphery model that inevitably defaults to Sinocentrism, the volume focuses on the productive transformations that occur when texts move beyond "local, regional, and 'national' boundaries" (p. xx). For instance, in the Japanese narrative histories that com- bine Japanese (wabun 和文) and Sinitic styles discussed by Michael McCarty (pp. 40-57 in chapter 2), Chinese historical events were not treated as events from a time and place far away. They were immediately relevant and capable of elucidating important moral lessons when paired with Japanese references. The term "Sinosphere" might suggest the centrality of China, but these and other examples show that "there was not one essential China that served as a reference culture for all writers in the Sinosphere" (pp. xxvii). This capacious conceptualization allows the possibility of even a "personal Sinosphere" (p. 70), free of political or cultural domination. As Sonja Arntzen shows for the Japanese monk Ikkyū 一休 (1394-1481), writers and monks from the Chinese past were models for personal identification and even sources of friendship (pp. 88-90 in chapter 3).

Instead of assuming a general, universal reference culture, the book's essays emphasize how Japanese, Koreans, and Vietnamese drew from the Sinosphere's wellspring. After all, early modern and premodern East Asian elites did not think of this culture as foreign to their own traditions. As Matthew Fraleigh shows in his chapter on Sinitic poetry in Japan, appending the label kan 漢 to distinguish Sinitic poetic forms from indigenous Japanese poetry was a relatively recent late nineteenth-century phenomenon. And even then, Japanese critics and writers of Sinitic poetry more likely saw 
their practices as continuous with the critical and literary traditions of the broader Sinosphere (pp. 252-60 in chapter 8). Even Mori Ōgai 森鴎外 (1862-1922), a "modern" author, integrated Japanese syntax, lexica, and puns into otherwise formally standard Sinitic poetry, melding Japanese and Sinitic registers into a distinct "Japanese-Sinitic," as John Wixted argues (pp. 281-86 in chapter 9). To be sure, it is not good enough to simply acknowledge that the Sinitic cultural repertoire was adapted in diverse ways, however useful it is for putting aside dated assumptions and national biases. The urgency is to make sense of how it was used. The essays in this volume generally offer compelling and distinctive examples in this vein; for instance, the integration of Tao Yuanming's 陶淵明 (365-427) eremitism with Neo-Confucian sensibilities in Chosŏn 朝鮮 (1392-1910) Korea described by Hong Cao (pp. 147-53 in chapter 5); the transmuted meanings of the Xiao Xiang landscape motif in both poetry and painting across Japan and Korea discussed by Luo I-fen (chapter 7); or how a courtly literary genre, the mudaishi 無題詩 (“poems that lack a verse topic," p. 169), moved into new, localized poetic registers in the poetry of the priest Renzen 連禪 (fl. 1149) in Ivo Smits's chapter (pp. 169-94 in chapter 6).

However successful the essays are individually, one still senses where the volume's conception confronts some limitations. Seven out of the ten essays address Japanese authors or traditions; only Keith Taylor's essay (chapter 10) on the employment of Sinitic referents and linguistic elements in vernacular poetic forms concerns Vietnam. (In the few essays that do mention Korea, Korean names are inconsistently Romanized, mixing two official Romanization systems, or even Chinese pinyin - editorial oversights that distract from the cosmopolitan thrust of the work.) More substantively, one wonders whether the lean towards Japan is what compels treating the Sinosphere primarily in terms of a cultural imaginary (as in the case of Bashō's 芭蕉 [1644-1694] use of tropes of eccentricity, discussed by Peipei Qiu [pp. 119-29 in chapter 4]). Without the political burden of reckoning with imperial China as a direct neighbor, Japanese authors enjoyed a luxury not always afforded Korean and Vietnamese writers of the same period. For them, political contact with imperial China - which they often relied upon for access to sinographic texts - meant that tributary hierarchy, frontier friction, and imperial irredentism lurked not far in the background. If these issues had been foregrounded in- stead, the literary rivalry (and the militaristic tropes describing them) discussed by Jongmook Lee (pp. 17-20 in chapter 1) would be cast in an entirely different light. Lee's essay, which opens the volume, hints at the nature of this problem: at least in Chosŏn Korea, the celebration of shared culture was promoted strongly through a diplomatic channel, with much at stake politically.

Moreover, the book repudiates the nation-state as a category, but its organization and approach are both fundamentally national. On some level, this reflects current conventions in the field, where literary specialists of East Asia are usually trained and employed in disciplines defined by modern national categories. But the volume also leaves out many bona fide members of the Sinosphere who are not ancestral to modern national formations and literary traditions: states with no modern successors (Bohai or Xi Xia), ethnic minorities in China (such as Hui Muslims), Ryūkyūans, and overseas Chinese in Nanyang and southern Vietnam to give some examples. Can a framework that emphasizes the circulation of culture, apt for individual thinkers or writers who could comfortably engage the Sinosphere without the burden of Chinese political hegemony, be sustained in contexts of marginalization or politicization? To be fair, these limitations are duly acknowledged by the book's editors (pp. xxxi-xxxii), and to address every outstanding issue is to set an impossible bar. After all, any book-especially one with ambition-has to make choices. In this case, these choices do not detract from the promise of the approaches represented in the book, but rather they elicit important questions and highlight the potential for further inquiry. 